selective oxidation processes. There is, however, reason to hope that repair of the neglect which gold has suffered in the past will generate new and exciting applications for this metal.

\title{
References
}

1 G. C. Bond, "Catalysis by Metals" (Academic Press, London, 1962), Chapter 5

2 W. R. Macdonald and K. E. Hayes, F. Catalysis, 1970, 18, (1), 115

3 Ref. 1, Chapter 8

4 D. D. Eley and D. R. Rossington, in "Chemisorption", ed. W. E. Garner (Butterworths, London, 1957), p. 137. See also S. J. Holden and D. R. Rossington, F. Phys. Chem., 1964, 68, 1061

5 B. J. Wood and H. Wise, 7. Chem. Phys., 1958, 29, 1416

$6 \mathrm{~W}$. M. H. Sachtler and J. Fahrenfort, Actes $2^{\text {mo }}$ Congrès Internat. Catalyse (Editions Technip, Paris, 1962), p. 831

7 G. Parravano, 7 . Catalysis, 1970, 18, 320
8 R. S. Yolles, B. J. Wood and H. Wise, 7. Catalysis, 1971, 21, 66 and earlier references quoted therein

9 British Patent 1,152,817; U.S. Patent 3,476,808

10 French Patent 2,007,925

11 U.S. Paten $3,553,220$

12 J. G. Hardy and M. W. Roberts, 7. Chem. Soc., D, Chem. Commun., 1971, (10), 494

13 M. Boudart and L. D. Ptak, F. Catalysis, 1970, 16, 90 14 D. D. Eley, F. Res. Inst, Catalysis, Hokkaido Univ,, 1968, 16, (1), 101

15 See for example British Patent 1,243,105; W. H. Flank and H. C. Beachell, F. Catalysis, 1967, 8, (1), 316

16 British Patents 1,246,015 and 1,103,125; German Patent $1,244,766$

17 G. C. Bond and E. G. Allison, unpublished work

\section{Gold in Silver Brazing Alloys}

\section{LOW MELTING POINTS WITH INCREASED DUCTILITY}

The well-known range of quaternary alloys based upon the silver-copper-cadmium-zinc system provides the lowest melting points of any silver brazing alloys. The addition of relatively small amounts of gold to alloys of this type extends even further the range of eutectiferous alloys available, and this characteristic can be utilised to design alloys with low melting points without large contents of zinc or cadmium and therefore with enhanced ductility.

The photomicrographs show the structures of two silver brazing alloys containing respectively 12.5 and 30 per cent by weight of gold. While their melting points, both in the range 630 to $660^{\circ} \mathrm{C}$, are comparable

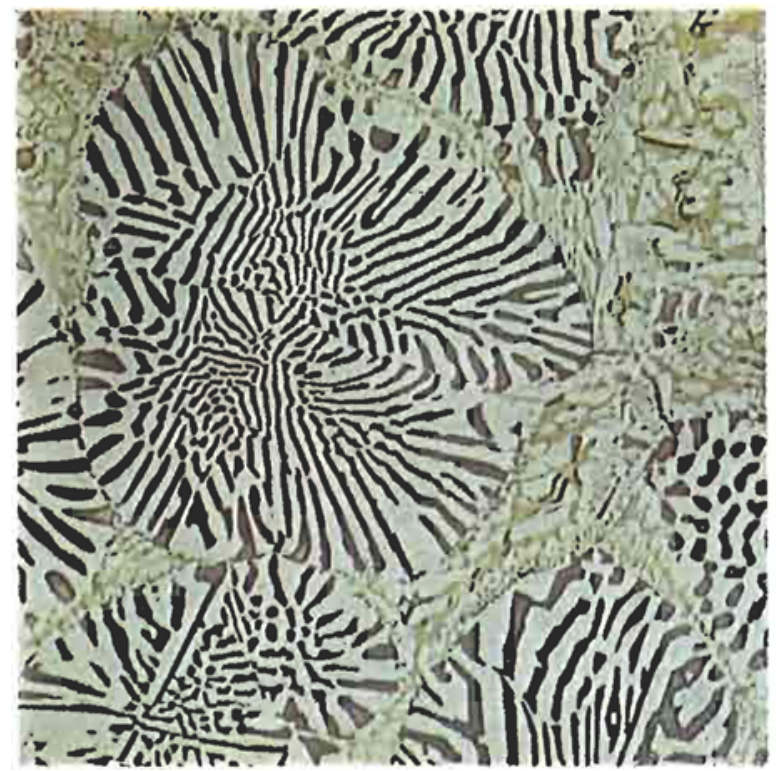

The eutectic structure of a low temperature silver braxing alloy containing 12.5 per cent gold. This has a liquidus of $660^{\circ} \mathrm{C}$ and a solidus of $630^{\circ} \mathrm{C}$ with those of the conventional quaternary silver solders the gold-bearing alloys produce joints that can readily be cold worked.

The usefulness of these alloys lies in the specialised field of composite structures in which gold is used as the surface coating or in the preparation of gold-clad base metals. In both cases the low temperatures needed to make the joints minimise the risks of surface contamination arising from either the substrate or the solder itself. They are particularly valuable when such combinations of gold and base metals must, after joining, be subjected to extensive rolling or drawing operations without annealing.

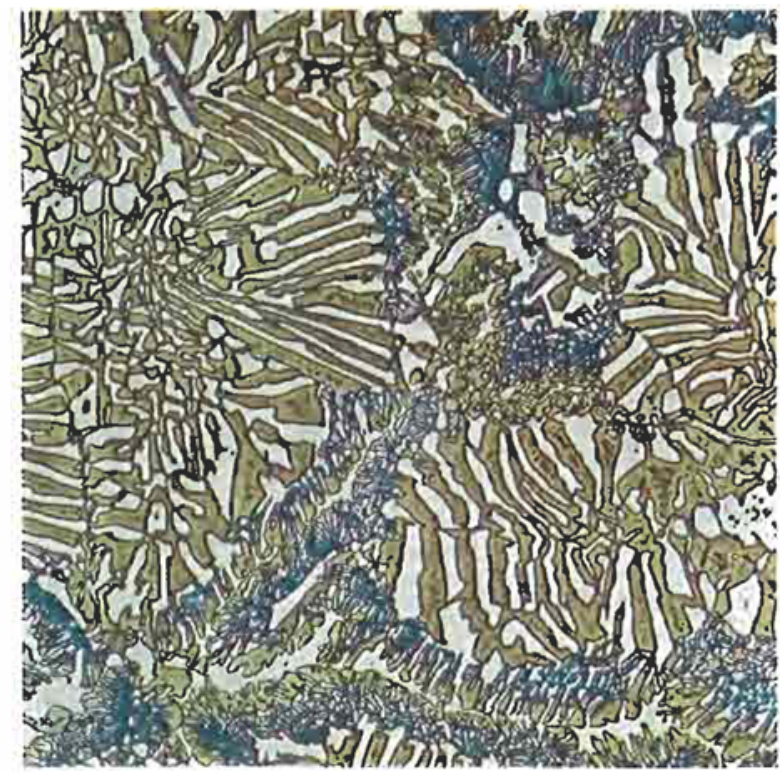

The structure of a similar alloy containing 30 per cent gold.

This also has a liquidus of $660^{\circ} \mathrm{C}$ witle a sotidus of $640^{\circ} \mathrm{C}$

$\times 125$ 